\title{
THEOLOGY: ITS DEFINITION, METHOD AND PLACE IN THE MODERN WORLD
}

\section{INTRODUCTION}

The subject of this article is theology in terms of its definition, method, scientific character and location. Since it is possible to distinguish several types of theology inter alia Jewish, Christian or Islamic, in this discourse, what is meant by "theology" is the Roman Catholic theology and by "Church" - the Roman Catholic one. By "theologian" is denoted "this member of the Church who by their studies and life in the community of the Church's Faith is qualified to pursue, in the scientific manner proper to theology, a deeper understanding of the Word of God and also to teach that Word by virtue of a canonical mission." Finally, what is indicated by "Magisterium" is "the task of the teaching that by Christ's institution is proper to the College of Bishops or to individual bishops linked in hierarchical communion with the Supreme Pontiff." 2

1 International Theological Commission, The Ecclesiastical Magisterium and Theology, thesis 1, accessed October 13, 2017 http://www.vatican.va/roman_curia/congregations/cfaith/cti_documents/ rc_cti_1975_magistero-teologia_en.html.

2 Ibidem, thesis 1. 
Thus, the goals of this paper are the following: firstly, to analyze some meanings of theology. Secondly, to reflect on its method. Thirdly, to discuss the issue of its scientific character. Fourthly, to try to determine its place in the modern world.

The article is addressed to both groups of scholars: theologians and non-theologians. For the former it is intended to be an attempt to summarize some selected aspects of the theological methodology. For the latter, to be an introduction to studies in theology. That is why I will often quote selected ecclesiastical documents especially those of Vaticanum II and the International Theological Commission (ITC).

The multiplicity and hence the variety of definitions of theologycoming from the etymology of the word itself (theos, logos), through the reference of its subject to God or man, or to the relation between both of them-may considerably hamper studies on this matter "from without". Nonetheless, to give an arbitrary, therefore artificial, definition of theology could result in halting its development. That can be why Magisterium has not given its official definition.

Having provided a definition of theology, I will be able to discuss its method. It is widely accepted that in order to call some reflection on reality a science, it has to be carried out systematically and with a method (in other words, not every use of the ratio can be called science). Having determined a manner, I will be able to reflect on the scientific character of theology, i.e. its status in the world of science.

Finally, I will discuss the place of theology in the modern society, in the contemporary world. Especially in the context of its presence at universities. This point is thought in reference to both the Pastoral Constitution "Gaudium et Spes" on the Church in the modern World and a paper by Joachim Ritter entitled The task of humanities in modern society.

\section{A DEFINITION OF THEOLOGY}

Theology assumes a prescientific assumption: there is the personal God who has spoken to man within the Revelation. Moreover, it "begins from the certitude of faith that the Paradosis of the Church and the dogmas it transmits are authentic statements of the truth 
revealed by God in the Old and New Testaments. It also affirms that the revealed truth, transmitted by the Paradosis of the Church, is universally valid and unchangeable in substance."3

The word "theology" (from now on abbreviated as "TH") refers to: (a) a field of study, (b) a process of theological cognition, (c) a result of this process, and (d) its subject. That is why TH describes (1) "what is planned within university studies;" (2) "what theologians do when they carry out their studies as theologians and present their results."

The foregoing meanings do not refer to the subject of TH in any way and as such they are worth very little because it is, first, the subject which specifies a science. The subjects of sciences can be divided as follows: the world (natural sciences), man (anthropological ones), personal human relations (social science, law), creativity (humanities). $\mathrm{TH}$, however, does not fit into this classification since it sometimes analyses the world (TH of creation, of science), sometimes it does man (theological anthropology, eschatology), still on other occasions, interpersonal relationships (moral $\mathrm{TH}$ ), and - finally $\mathrm{TH}$ analyses human creativity ( $\mathrm{TH}$ of culture). From the aforesaid it cannot be concluded that $\mathrm{TH}$ is partially ascribed to the set of humanities and partially to that of social sciences, but that it should utilize the methods of humanities and social sciences.

It seems right to mention other definitions of TH. (3) the human reflection on the revealed (supernatural) articles of faith; (4) an attempt to understand the Revelation i.e. the divine word addressed to man; (5) an attempt at the rational reflection on the own articles of faith, i.e. in the light of the rational knowledge; (6) the science of God and of relation between Him and both man and the world; (7) a class of studies explaining the content of beliefs (including

3 International Theological Com mission, The interpretation of Dogma, A, II, 1, accessed October 13, 2017 http://www.vatican.va/roman_curia/ congregations/cfaith/cti_documents/rc_cti_1989_interpretazione-dogmi_en.html. (Paradosis means Tradition and it is from the German text of citated document).

${ }^{4}$ A. B r o n k, S. M aj d a ń s k i, Teologia-próba metodologiczno-epistemologicznej charakterystyki, „Nauka” 2006 nr 2, p. 88. 
dogmas). To the above short statements, one can add a few more descriptive ones concerning $\mathrm{TH}$ : (8) responding to "the invitation of truth as it seeks to understand the faith. It thereby aids the People of God in fulfilling the Apostle's command (cf. 1 Pet 3:15) to give an accounting for their hope to those who ask it;", (9) gaining, "by way of reflection, an ever deeper understanding of the Word of God found in the Scripture and handed on faithfully by the Church's living Tradition under the guidance of the Magisterium;" ${ }^{\prime 6}(10)$ an attempt to "clarify the teaching of Revelation with regard to reason and giving it finally an organic and systematic form."

It should be underlined that just in (6) it is claimed that $\mathrm{TH}$ is the science of God. In the others the attention is drawn to such elements as human reflection, the Revelation and the articles of faith. Regardless of differences, there can be no doubt that the subject of $\mathrm{TH}$ is the supernatural reality which does not fit simply empirical approaches and because of it is similar to metaphysics. One utterance of Magisterium should be stressed as well: "the object of TH is the Truth which is the living God and His plan for salvation revealed in Jesus Christ" therefore "the theologian is called to deepen his own life of faith and continuously unite his scientific research with prayer" and he must "be attentive to the epistemological requirements of his discipline, to the demands of rigorous critical standards, and thus to a rational verification of each stage of his research." "This statement has to be specified. The subject of TH must be God who through the event of Jesus Christ and the event of the gift of the Holy Spirit has revealed himself to us. That is why "the fundamental axiom of modern TH is best put in the following terms: the Trinity that manifests itself in the economy of salvation is an immanent Trinity,

${ }^{5}$ Congregation for the Doctrine of the faith, Instruction Donum Veritatis on the ecclesial vocation of the theologian, 6 accessed October 13, 2017 http://www.vatican.va/roman_curia/congregations/cfaith/documents/ rc_con_cfaith_doc_19900524_theologian-vocation_en.html.

6 Ibidem, 21 .

7 Ibidem.

8 Ibidem, 8. 
and it is this Trinity that gives itself freely and graciously in the economy of salvation." 9

That is why, at this point, I define $\mathrm{TH}$ as the critical human reflection, driven by faith, on the articles of faith. $\mathrm{TH}$ leads to the ever deeper understanding of these truths, not adding anything to the Gospel but proclaiming the novelty of Christ every single time in a new way.

From the above it follows that $\mathrm{TH}$ has a specific identity. It is linked to both the authority of the Revelation and to faith in this Revelation. Furthermore, TH is an ecclesial science and it means that the theologian has to accept the authority based on the obedience of faith: "«an act of divine and Catholic faith must be made in what is contained in God's Word, either as it is written in the Scripture or handed on by tradition and proposed by the Church, whether that be by way of a solemn decision or by the ordinary Magisterium, and the obligation to believe is demanded because it is the divine Revelation». This credendum includes the truths of faith (in the strict sense) and also those truths, witnessed to by revelation, which have a bearing on the moral life... Other statements of the Magisterium which, without being definitive definitions, come from the Pope, the Congregation for the Doctrine of the Faith or from the bishops, must equally be accepted, in varying degrees, with religious assent (religiosum obsequium)." 10 To put it in another way: "the authority that belongs to $\mathrm{TH}$ in the Church is not merely profane and scientific but it is a genuinely ecclesial authority, inserted into the order of authorities that derive from the Word of God and are confirmed by the canonical mission."

9 International Theological Commission, Theology, Christology, Anthropology, I, C, 2 accessed October 13, 2017 http:// www.vatican.va/roman_curia/congregations/cfaith/cti_documents/ rc_cti_1982_teologia-cristologia-antropologia_en.html.

${ }_{10}$ International $\mathrm{The}$ ological $\mathrm{Com} \mathrm{m}$ is sion, The interpretation..., op. cit., B, II, 3 .

${ }^{11}$ International Theological Commission, The Ecclesiastical Magisterium..., op. cit., thesis 6. 
Having defined TH and having stated its characteristics, I will try to answer the question whether $\mathrm{TH}$ has a method.

\section{THEOLOGICAL METHOD}

Węcławski notes that "from the perspective of the daily scientific and didactic work of theologians, the overwhelming majority of what they do as scholars and teachers is quite comparable to the activities of the representatives of other sciences belonging to humanities - with respect to both the subject matter of research (there are mostly texts and, to a lesser extent, empirical data) and the applied method." He is, however, aware of the need to explain "what makes theologians' work TH and, to what degree, acting within the proper framework of TH changes (or not) the characteristics of methods and procedures shared with other humanities." 12 [Highlighting comes from me] This scholar places TH within humanities. Therefore, the method and proprium of $\mathrm{TH}$ should be here reflected on.

The word "method" etymologically derives from gr. methodos (latin methodus) and means: a way, method of studying, lecturing or acting. This lexeme means (I) the mode of operation, the choice of type of action, knowingly used with the possibility of repetition in all cases of a given type; (II) a set of activities and measures that are used in a certain way to achieve a particular purpose; (III) a way to perform a practical task or to solve a theoretical problem; (IV) a set of general assumptions assumed as the framework or guidelines for the study. In other words, to speak about the method of $\mathrm{TH}$, I must first define its purpose.

The purpose of $\mathrm{TH}$ is "«to preserve the sacred deposit of Revelation, to examine it more deeply, to explain, teach, and defend it,» for the service of the People of God and for the whole world's salvation."13 The task of TH is thus systematization (preservation, ever

12 T. Wę c ła w s k i, Metodologia teologii, „Poznańskie Studia Teologiczne” 18(2005), p. 8.

${ }^{13}$ International Theological Commission, The Ecclesiastical Magisterium..., op. cit., thesis 2. 
deeper examination, teaching) and justification (defending) its claims and deriving new ones which can be subject to verification on the assumption that they "have their ultimate basis in the very mystery of Christ" which "goes beyond the possibilities of expression of any given age and thus eludes exhaustive systematization."14

Systematization and justification can be considered in terms of either global methods or methods of the teaching of particular issues. The former ones are to organise the theological theme around a specific leading thought e.g. theocentrism, Christocentrism, the history of salvation or anthropocentrism. The latter ones explore individual theological truths and are divided into scholastic, positive, mixed, partial and integral methods. The last one seems to be the most general in terms of relevance not only to dogmatic TH. There are eight $(\mathrm{A}-\mathrm{H})$ elements outlined in its diagram ${ }^{15}$ which I will discuss one by one.

A) Presenting and analysing all sources of $\mathrm{TH}$ on a given topic. The theologian deals first with texts: "the fundamental criterion is the Scripture as it relates to the confession of the believing and praying Church. Among dogmatic formulas, those of the earlier Councils have the priority." ${ }^{\prime 16}$ Nonetheless, the theologians are not bound only by the Word of God, but also by the sense of faith, the documents of Tradition and the pastoral and missionary concern.

B) Including the so-called analogy of faith, i.e. links to other articles of faith. In Christology it can mean expounding the relationship of Christology to the other ways of talking about God and to the faith in the Triune God.

14 International The ological Com mission, Unity of the Faith and theological pluralism, 1, accessed October 13, 2017 http://www.vatican.va/roman_curia/ congregations/cfaith/cti_documents/rc_cti_1972_fede-pluralismo_en.html.

15 J.D. S z c z u r e k, Trójjedyny: traktat o Bogu w Trójcy Świętej jedynym, Kraków 1999, p. 46.

${ }^{16}$ International The ological Com mission, Unity of the Faith..., op. cit., 7 . 
C) A rational deepening by introducing unambiguously defined concepts. Although "a process of contemporary interpretation is not a purely intellectual enterprise, nor for that matter purely existential or sociological" nor does it "consist exclusively in more precise definition of individual concepts, nor in the reshaping or invention of formulations," of interpretation, teaching, and translation into contemporary modes of thought, insert the teaching and warnings of the Magisterium into a wider, synthetic context and thus contribute to a better knowledge on the part of the People of God. In this way, «they lend their aid to the task of spreading, clarifying, confirming, and defending the truth that the Magisterium authoritatively propounds»." 18

D) Presenting references, if any, to other fields of knowledge, since $\mathrm{TH}$, "in the light of the universal Church's tradition," examines "the words and deeds which God has revealed, and which have been set down in the Sacred Scripture and explained by the Fathers and by the Magisterium"19 from the moment "the recent studies and findings of science, history and philosophy raise new questions... which demand new theological investigations." ${ }^{20}$ It is this moment that allows us to appreciate new methodological achievements in an interdisciplinary aspect: "many of the perspectives made available by the historico-critical method and more recent methods (the history of comparative religions, structuralism, semiotics, social history, depth psychology) may

17 International The ological Commission, The interpretation..., op. cit., C, III, 2.

18 International Theological Commission, The Ecclesiastical Magisterium..., op. cit., thesis 5.

19 Decree "Ad Gentes" on the mission activity of the Church, 22 accessed on October 13, 2017 http://www.vatican.va/archive/hist_councils/ii_vatican_council/ documents/vat-ii_decree_19651207_ad-gentes_en.html.

20 Pastoral Constitution "Gaudium et spes" on the Church in the modern World, 62 accessed on October 13, 2017 http://www.vatican.va/archive/hist_councils/ ii_vatican_council/documents/vat-ii_cons_19651207_gaudium-et-spes_en.html. 
help to put the figure of Christ in greater relief for men of our time." ${ }^{21}$ However, all these methods may turn out fruitful only to the extent they are used in the obedience of faith and do not aim at autonomy.

E) Discussing the teachings of other churches (ecumenical aspect). According to the teaching of Vaticanum II the theologian "must get to know the outlook of our separated brethren. To achieve this purpose, the study is of necessity required, and this must be pursued with a sense of realism and good will. Catholics, who already have a proper grounding, need to acquire a more adequate understanding of the respective doctrines of our separated brethren, their history, their spiritual and liturgical life, their religious psychology and general background." 22

F) A reference to the liturgy which expresses the faith of the Church on a given subject.

G) Defining theological qualifications (distinguishing the content of the divine and catholic faith from theological views, i.e. giving a level of theological certainty). It can happen that "a theologian may, according to the case, raise questions regarding the timeliness, the form, or even the contents of magisterial interventions. Here the theologian will need, first of all, to assess accurately the authoritativeness of the interventions which becomes clear from the nature of the documents, the insistence with which a teaching is repeated, and the very way in which it is expressed." ${ }^{23}$ In this light "dogmatic formulations must be considered as responses to precise questions, and it is in this sense that they remain always true," 24 and new proposals

${ }^{21}$ International The ological Commis sion, The interpretation..., op. cit., C, I, 4.

22 Decree "Unitatis redintegratio" on ecumenism, 9 accessed October 13, 2017 http://www.vatican.va/archive/hist_councils/ii_vatican_council/documents/ vat-ii_decree_19641121_unitatis-redintegratio_en.html.

${ }^{23}$ Congregation for the Doctrine of the faith, op. cit., 24.

${ }^{24}$ International Theological Commis sion, Unity of the Faith..., op. cit., 10. 
advanced for understanding the faith are "an offering made to the whole Church. Many corrections and broadening of perspectives within the context of fraternal dialogue may be needed before the moment comes when the whole Church can accept them." Consequently, "this very disinterested service to the community of the faithful," which is TH, "entails in essence an objective discussion, a fraternal dialogue the openness and willingness to modify one's own opinions." 25 That is why I do not agree with the opinion of ITC members that "it is desirable before all else to avoid the Church's authority becoming pointlessly blunted, that the Magisterium itself should, on every occasion, indicate the type and degree of obligation of the statements issued," 26 unless it were a definitive statement.

H) Indicating practical implications in internal and pastoral life (karygmatic aspect). In other words, how to apply general principles to concrete circumstances. Those general principles are, inter alia, the precepts and examples of the Son of God, who reveals the heart of His Father; the life according to the Spirit in the bosom of the Church.

The analysis of the documents of the Church allows us to postulate to add another stage to the theological method $-\left(^{*}\right)$ the historicalculture analysis. "Since reality is always more vast and more profound than all its representations and conceptualizations, as these are conditioned for us by history and culture as we elaborate them, it is imperative to seek a constantly renewed and deepening interpretation of such cultural traditions." 27

The integral method, thus, exhausts Węcławski's four theological methods ${ }^{28}$ : TH as (i) the commentary, i.e. the hermeneutics of the

25 John Paul II, Discorso di Giovanni Paolo II ai professori di teologia accessed October 13, 2017 http://w2.vatican.va/content/john-paul-ii/it/speeches/1980/ november/documents/hf_jp_ii_spe_19801118_professori-teologia.html.

${ }^{26}$ International The ological $\mathrm{Comm}$ is sion, The interpretation..., op. cit., B, II, 3 .

27 Ibidem, A, I, 3.

${ }^{28}$ T. W ę cław s k i, art. cit., pp. 15-21. 
sources of the Revelation, (ii) the system of questions and answers, (iii) the reflection on the history of faith and (iv) the reflection on the social situation of faith and religion.

In search of new theorems, TH refers to the speculative method, the rules of proving and verifying. These methods use deduction, or, more broadly, formal logic. It should be remembered, withal, that "the development of dogmas is a vital process which is too complex to be regarded as simply a logical explanation and the deduction from given premises. Nevertheless, there must be logical coherence between the conclusions and the initial data. Conversely, one can judge what a development is from its consequences or recognize it as legitimate or otherwise by its fruits." 29

The outlined procedure clearly identifies the way in which the type of action is consciously applied along with the possibility of repetition in all cases of the type, i.e. the definition of method (I) is exhausted.

Having worked out the definition of TH in the context of its subject and having discussed its methodological proposal, I will reflect on the scientific character of $\mathrm{TH}$, particularly its place in the world of science.

\section{THE SCIENTIFIC CHARACTER OF TH}

The scientific character of TH cannot be justified in a trivial way as, for example, Szymik does, writing that it is "scientia, a science because it belongs to sciences as it makes use of the mind (sic!) but fidei (it is of faith - so that it is a science different from the other ones because it uses, as none of them, the faith which irrevocably and constitutively contributs to theological methodology)." ${ }^{30}$ Moreover, Szymik explicitly defines the TH as scientia sui generis. I think this is too simplistic. Such a circumscribing of the methodological distinctiveness of $\mathrm{TH}$ - made even implicitly - de facto makes it

${ }^{29}$ International The ological Commis sion, The interpretation..., op. cit., C, III, 5.

${ }^{30} \mathrm{~J}$. S z y $\mathrm{m}$ i k, Teologia jako nauka wiary, czyli scientia sui generis, ,Śląskie Studia Historyczno-Teologiczne" 32(1999), p. 96. 
impossible to count it among sciences. That is because "price for conferring on $\mathrm{TH}$ a methodologically privileged status" - that "sui generis" - "in the sense that it would only be assessed "from within», would be its cognitive immunity. It would exclude theological theories and theses from the intersubjective control (sensibility and verifiability), which is a necessary (although not the only one) condition for the recognition of a certain field of knowledge as rational." ${ }^{31}$

The relationship between the faith and TH must be specified. The faith does not create theological methodology, as Szymik wants, but it can (should) lead to $\mathrm{TH}$ which is a methodical reflection on the articles of faith. $\mathrm{TH}$, "appealing to the understanding of those who do not yet know Christ, helps them to seek and find faith". TH "obedient to the impulse of truth which seeks to be communicated, also arises from love and love's dynamism. In the act of faith, man knows God's goodness and begins to love Him. Love, however, is ever desirous of a better knowledge of the beloved. From this double origin of TH, inscribed upon the interior life of the People of God and its missionary vocation, derives the method with which it ought to be pursued in order to satisfy the requirements of its nature." 32

Also, a pragmatic justification presented by Węcławski is unsatisfactory ${ }^{33}$ because the position of TH should be derived from its epistemological status rather than the scholar community's agreement. Nonetheless, he clearly indicates the place of the rationality of TH. Although accepting "a source of knowledge absolutely distinct from that which is accepted by all other sciences" - as a result of the presence of "theos" in its name - TH "subjects all its own statements to rational verification, as long as the verification system does not exclude claims of objects not directly presented, in other words, on condition that metaphysics is accepted." ${ }^{34}$

\footnotetext{
31 A. Bronk, S. M ajd ańs ki, art. cit., p. 86.

${ }^{32}$ Congregation for the Doctrine of the faith,op. cit., 7.

33 T. W ę c ła s s k i, art. cit., p. 8.

34 Ibidem, p. 10.
} 
In the like manner, Müller's argument seems inadequate: "TH has a scientific character becuse its subject is not a purely factual arrangement, but an engaging and provocative personal relationship." 35 This engaging and provocative personal relationship, which is the faith, can be regarded as the second criterion of the rationality of $\mathrm{TH}$, which is the question of truth, that is, the life, death and resurrection of the man, Jesus Christ ${ }^{36}$.

TH is a science as long as it has its own subject and its own method. It belongs to the family of sciences also because it develops (it is not definitive). There are two factors that contribute to the development of TH. The inner one which results from the desire to understand one's own faith in terms of knowledge already possessed and in the language understood by modern humans and the external one (e.g. the will to defend the Christian doctrine from charges against it by the Jewish community or the heathen in the early years of Christianity). Let me quote from Magisterium: "because the Christian Faith is universal and missionary, the events and words revealed by God must be each time rethought, reformulated, and lived anew within each human culture, if we wish them to make the true response to problems rooted in the heart of every human being and to inspire the prayer, the worship, and the daily life of the people of God."'37

A reflection on reality can be called a science if its theories and theses are subject to intersubjective control (sensibility and verifiability). Therefore, I will consider whether these conditions are fulfilled by TH. In other words, I will answer the question whether the language of TH is internally meaningful and externally comprehensible.

The theological language is varied according to the concepts and borrowings from philosophy or other sciences. Since "the Church must at all times have the history of her faith in a memoria animated

35 G.L. M ü 11 e r, Chrystologia: nauka o Jezusie Chrystusie, Kraków 1998, p. 37.

36 T. Wę cł a s s k i, art. cit., p. 10.

${ }^{37}$ International Theological Commission, Unity of the Faith..., op. cit., 9 . 
by the Holy Spirit; and she must present it vibrantly and vitally in a prophetic way for now and for the future" 38 the theologian is called to use "philosophical concepts which provide «a solid and correct understanding of man, the world, and God» and can be employed in a reflection upon revealed doctrine." Moreover, "the historical disciplines are likewise necessary for the theologian's investigations. This is due chiefly to the historical character of Revelation itself which has been communicated to us in "salvation history»." They should finally consult the human sciences as it "is also necessary to understand better the revealed truth about man and the moral norms for his conduct, setting these in relation to the sound findings of such sciences." That is need to be underlined that "when TH employs the elements and conceptual tools of philosophy or other disciplines, discernment is needed. The ultimate normative principle for such discernment is revealed doctrine which itself must furnish the criteria for the evaluation of these elements and conceptual tools and not vice versa," 39 as studies on dogma's history show "the Church has not simply taken up already existing conceptual schemes. She has rather subjected existing concepts, imprinted by the upper levels of the language of the milieu, to a process of purification and transformation, or reworking... The language of the Church's dogma was then forged partly in debate with certain philosophical systems, but is not bound in any way to any definitive philosophical system. In the process of seeking language for the faith, the Church has created a language of her own in which she has given expression to realities hitherto unperceived and unknown, but which belong now, precisely by means of such linguistic expression, to the Paradosis of the Church and through it to the historical heritage of humanity." ${ }^{\prime \prime}$

${ }^{38}$ International The ological Commission, The interpretation..., op. cit., B, III, 1.

${ }^{39}$ Congregation for the Doctrine of the faith,op. cit., 10.

${ }^{40}$ International The ological Commission, The interpretation..., op. cit., C, III, 3. 
The language of TH is therefore internally meaningful because there are criteria for accepting or rejecting a proposed formula. However, it should be noted that there is a specific instance of falsification in TH. It is the Magisterium which has a special "charism of infallibility in matters of faith and morals. This charism is manifested when the Pastors propose a doctrine as contained in Revelation and can be exercised in various ways. Thus it is exercised particularly when the bishops in union with their visible head proclaim a doctrine by a collegial act, as is the case in an ecumenical council, or when the Roman Pontiff, fulfilling his mission as supreme Pastor and Teacher of all Christians, proclaims a doctrine «ex cathedra»." ${ }^{.41}$

Theologians themselves should be concerned about the external perception of the language proper to TH because they "insert the teaching and warnings of the Magisterium into a wider, synthetic context and thus contribute to a better knowledge on the part of the People of God" by "interpretation, teaching, and translation into contemporary modes of thought." ${ }^{\text {42 }}$

$\mathrm{TH}$ is therefore a science independent of the opinion of the scholars' community, and that is because of its object, its method, its language and its development. All of this makes it subject not only to an internal evaluation, however, with one reservation: there are two key elements in the methodological evaluation of the theologian's work and TH as such: the ability to make the competent use of their own and borrowed scientific method and their position in the context of the historical experience of the Church's faith. Therefore, the first part of the assessment can be made by every scientist while the other one only by another theologian.

The last purpose of this paper is to consider the location of TH as science and its legitimacy as part of a university study.

${ }^{41}$ Congregation for the Doctrine of the faith, op. cit., 15.

${ }^{42}$ International The ological Commission, The Ecclesiastical Magisterium..., op. cit., thesis 5. 


\section{PLACE OF TH}

Since $\mathrm{TH}$ is a science and, as it seems, a humanistic one, its presence at university is formally justified. Nonetheless, it should be asked whether it is also justified practically. This issue will be the subject of the last part of this paper.

Vaticanum II recalls that "through his labors and his native endowments man has ceaselessly striven to better his life... hence many benefits once looked for, especially from heavenly powers, man has now enterprisingly procured for himself." 43 This is the result of the development of technical sciences. Therefore, the university "as an institution focused on human education through its participation in pure cognition and research," writes Ritter, "is ostensibly in fundamental contradiction to the indispensable needs of industrial society." ${ }^{44}$ Does this mean that there is no place for the university in the time of technology? On the one hand, the answer to the question about the purpose of science and technology can be reduced to their practical use. This possibility does not exist in the humanities whose subject is history, language, poetry, philosophy, religion, etc. On the other hand, however, "though mankind is stricken with wonder at its own discoveries and its power, it often raises anxious questions about the current trend of the world, about the place and role of man in the universe, about the meaning of its individual and collective strivings, and about the ultimate destiny of reality and of humanity.' 45

Ritter, continuing his lecture, notes that "theoretical science belongs to polis to reveal in fornt of it ascendancy in the world." 46 Vaticanum II states that among the contemporary people "agitate numerous questions among themselves. What is the meaning and

43 Gaudium et spes, 33.

44 J. R i t t e r, Zadanie nauk humanistycznych w społeczeństwie współczesnym, in Studia z filozofii niemieckiej, S. Czerniak, J. Rolewski (edds.), Toruń 1996, pp. 18-19.

45 Gaudium et spes, 3.

46 J. R it t e r, art. cit., p. 21. 
value of this feverish activity? How should all these things be used? To the achievement of what goal are the strivings of individuals and societies heading?"47

Here the role of $\mathrm{TH}$ in the modern world is revealed. The function of $\mathrm{TH}$ is to combine the light of Revelation with the experience of all men, to illuminate the way humanity enters, but not always with the answer to the particular question or desire. The world "demands humanities which make man in his social being understand the substantial structures of human existence that society cannot give him. ${ }^{448}$ So that the theologian enters into a dialogue with man about these problems bringing "light kindled from the Gospel, and puts at its disposal those saving resources which the Church herself, under the guidance of the Holy Spirit, receives from her Founder." 49

"The presence of $\mathrm{TH}$ at the university is a valuable legacy to be defended. TH lives and takes place in the «home of science», and it is important for both $\mathrm{TH}$ and the other sciences" $" 50$ because their common denominator is man.

\section{SUMMARY}

This article has presented a definition and methodology of the TH, discussed the issue of its scientific character and its place among the sciences and at the university.

The paper has been written for two groups of readers: theologians and non-theologians. For the first ones, it has been intended to summarize selected aspects of the methodology of this scientific discipline, while for the others to introduce to studies in $\mathrm{TH}$.

In the essay some selected definitions of $\mathrm{TH}$ have been cited in order to extract them what is constitutive to $\mathrm{TH}$ as a science. The

\footnotetext{
47 Gaudium et spes, 33.

48 J. R it t e r, art. cit., p. 42.

49 Gaudium et spes, 3.

50 J. R a t z i n g e r, Prawda w teologii, Kraków 2001, p. 146.
} 
following elements have been distinguished: faith, thought, revealed truths.

Then the method of TH has been set out, having selected an integral method as an example. It has been selected because it is suitable not only for research in dogmatic TH but for other theological sub-disciplines as well.

Talking about the scientific character of $\mathrm{TH}$, the focus has been on the language of TH. It has been found to be internally meaningful and externally comprehensible, and therefore $\mathrm{TH}$ is subject to scientific criticism not only from the inside but also under certain conditions from the outside.

The discourse has been concluded with a reflection on the justification for the presence of $\mathrm{TH}$ at the university, stating that the task of this science is to analyze reality in the context of the harmonious development of man and the proper use of goods, that is, the complementation of natural sciences.

\begin{abstract}
This article presents theology in three aspects: definitions, methods and places in the modern world. The definition is derived using the statements of the ecclesiastical Magisterium. A reflection on the method is based on some selected academic publications and the ecclesiastical Magisterium statements, too. The basis for a brief reflection on the place of theology is J. Ritter's thought and the statement of the ecclesiastical Magisterium ("Gaudium et Spes"). The article is addressed to both theologians and the representatives of other sciences.
\end{abstract}

\title{
Streszczenie \\ TEOlOGIA: JEJ DEFINICJA, METODA I MIEJSCE WE WSPÓECZESNYM ŚWIECIE
}

Artykuł przedstawia teologię w trzech asperktach: definicji, metody i miejsca we współczesnym świecie. Definicja jest ukuta na podstawie wypowiedzi Magisterium Kościoła. Refleksja nad metodą jest oparta na wybranych publikacjach akademickich oraz wypowiedziach Magierium Kościoła. Podstawą krótkiej refleksji 
odnośnie do miejsce teologii jest myśl J. Rittera oraz Gaudium et Spes. Artykuł jest adresowany zarówno do teologów, jak i nieteologów.

Key words: theology, method, dogma, Magisterium

Słowa kluczowe: teologia, metoda, dogmat, Magisterium

\section{Bibliografia}

Bronk A., Majdański S., Teologia-próba metodologiczno-epistemologicznej charakterystyki, „Nauka” 2006 nr 2, pp. 81-110.

Congregation for the Doctrine of the faith, Instruction Donum Veritatis on the ecclesial vocation of the theologian, accessed October 13, 2017 http://www.vatican.va/roman_curia/congregations/cfaith/documents/ rc_con_cfaith_doc_19900524_theologian-vocation_en.html.

International The ological Comm is sion, The Ecclesiastical Magisterium and Theology, accessed October 13, $2017 \mathrm{http}: / /$ www.vatican.va/roman_curia/ congregations/cfaith/cti_documents/rc_cti_1975_magistero-teologia_en.html.

International Theological Commission, The interpretation of Dogma, accessed October 13, 2017 http://www.vatican.va/roman_curia/congregations/cfaith/cti_documents/rc_cti_1989_interpretazione-dogmi_en.html. (Paradosis means Tradition and it is from the German text of citated document).

International Theological Commission, Theology, Christology, Anthropology, accessed October 13, 2017 http:// www.vatican.va/roman_curia/congregations/cfaith/cti_documents/ rc_cti_1982_teologia-cristologia-antropologia_en.html.

Inter national The olog i a l Co m m is sion, Unity of the Faith and theological pluralism, accessed October 13, $2017 \mathrm{http} / /$ www.vatican.va/roman_curia/ congregations/cfaith/cti_documents/rc_cti_1972_fede-pluralismo_en.html.

Mü 11 e r G.L., Chrystologia: nauka o Jezusie Chrystusie, Kraków 1998.

R a tzinger J., Prawda w teologii, Kraków 2001.

$\mathrm{R}$ it t e r J., Zadanie nauk humanistycznych w społeczeństwie wspótczesnym, in Czerniak S., Rolewski J., Studia z filozofii niemieckiej, Torun 1996, pp. 17-43.

S z c z u r e k J.D., Trójjedyny: traktat o Bogu w Trójcy Świętej jedynym, Kraków 1999.

S z y m i k J ., Teologia jako nauka wiary, czyli scientia sui generis, „Śląskie Studia Historyczno-Teologiczne" 32(1999), pp. 95-104.

W ę cławski T., Metodologia teologii, „Poznańskie Studia Teologiczne” 18 (2005), pp. 7-24. 